\title{
Social Studies Education and Entrepreneurship for Youth Empowerment in Nigeria
}

\author{
Ipenyi Peter Edor \\ Department Of Social Studies \\ College Of Education, Oju, Benue State,Nigeria
}

\section{Doi:10.5901/mjss.2013.v4n12p31}

\begin{abstract}
One of the world millennium concerns is the reduction of poverty and acceleration in economics, social, physical growth, development and youth empowerment. This paper examines the need for incorporating entrepreneurship skills into social studies education curriculum with the views to attaining job creation, which will enhance youth empowerment. It is assumed that Nigeria has the highest rate of poverty, unemployment, corruption, among other social problems that need to be addressed. These socio-economic problems need to be solved using different strategies for solving those social problems. It is in the light of these, that social studies and entrepreneurship education are out to fight those anti-social problems which will go a long way in enhancing youth empowerment, which will serve a complementary role in creating job opportunities in support of the federal Government. If all hands are on deck, issue of poverty, unemployment and corruption etc will be a thing of the past. The conclusion was done with some recommendations.
\end{abstract}

\section{Introduction}

In the world today, advancement in information technology, social studies and entrepreneurship education has reduced the entire world to a village status thereby intensifying competition in fields of endeavors. This competitive and ever-changing environment has posed serious survival challenges to all individuals and nations of the world as it affects youth empowerment. One of the basic requirements for survival in this kind of contestable environment is to embrace the entrepreneurial spirit that can enable individual and nations to identify and exploit these opportunities as well as positively approach the threat for improved job opportunities. It was in the wake of this that an Austrian Economist, Joseph Schumpeter (1949) once argued that entrepreneurship was the engine of youth empowerment and national development.

Entrepreneurship education seeks to provide for knowledge, skills and motivation to encourage entrepreneurial success in a variety of settings. It also strives to educate them about the benefits of entrepreneurship, which is a distinctive area of education as it focuses on realization of opportunity (Wikipedia, the free Encyclopedia).

In this paper, the writer has also decided to explore the meaning of social studies education, entrepreneurship, of which both courses are seen as tools for realizing some objectives of the Nigerian educational system as contained in the National policy of education, which also formed the main area where the aims and objectives of social studies and entrepreneurship education is drawn from. The objectives are thus (Federal Ministry of Education 2008):

$>$ The inculcation of the type of values and attitude for the survival of the individual and the Nigeria society

> The training of the mind in the understanding of the world around and

> The acquisition of appropriate skills and the development of mental, physical, and social abilities and competence as equipment for the individual to live in and contribute to the development of the 
society.

This paper also view the concept of social studies and entrepreneurship activities and how well these could be used to solve most anti-social problems, which will solve problems of youth employment but some recommendations were made as the concluding note.

\section{The Concept of Social Studies Education}

Aduralegbe (1980 pp 2-3) defines social studies as a problem approach discipline through which man studies and learn about problems of survival in his environment. It is an inter-disciplinary study of a topic, a problem issue, a concern or an inspiration. It is a study of how man influences and in turn is influenced by his physical, social, political, economic, psychological, cultural, scientific and technological environment.

While Okobia (1984), defined social studies as a subject for inculcating the right type of skills and civic virtue through unified and integrated inter-disciplinary studies of man that the planners of the national policy on education it a pre-eminence of place within the core subjects of the Junior Secondary school curriculum.

On the other hand, Akinlaye (1981) puts it thus, pupils in the classroom do not have adequate information to touch, feel, smell, build, destroy, analyze, synthesize for developing ideas and learning to take decisions. A large section of our educational system is bound to an academic bookish and sedentary curriculum wholly irrespectant to life and needs of any modern society. He went on to assert that, social studies emerged then as a subject of prime importance for study in schools. It involves a study of basic characteristic of man, a detailed investigation into the way and varied expressions of the adoption of man to the area in which he lives and his relationship with other men.

\section{The Concept of Entrepreneurship}

This concept of entrepreneurship has been variously defined by different scholars, stoner, freeman and Gilbert (2001) defined it as the seeming discontinuous process of combining resources to produce new goods and services. In the view of Zuomo J.T and Aondooko E.K (2007) entrepreneurship is the process of identifying and bringing a vision to life. The vision according to them may be an innovative idea, an opportunity or simply a better way of doing something. The end result of this process is the creation of a new venture under conditions of risk and considerable uncertainty. The challenges of youth unemployment in Nigeria have been observed to be increasing sharply from the end of 2008. This scenario of rising youth unemployment has been worsened by the recent world economic crisis that began in 2009, which eroded in the pre 2008 years.

\section{Conceptual explications}

Youth: The concept that represents youth is devoid of unanimous definition among social scientist and analysts. Biologically, youth is the quality of being young, youthfulness and juvenility. It is that aspect of one's existence that succeeds the childhood stage but precedes the adult age. Apart from the biological perspectives, other allusions to the youth concept borders commonly on agreed aspects as rate of dependency on parents, physical development, behavioral tendencies and age categorizations.

For this paper, we are adopting the age to distinguish the concept of a youth, as a result of the fact that, this age variable is more commonly accepted across countries. In line with this, the maximum age limit for a youth is pegged at the age of 30 years as reflected in the National Youth Service scheme. In Nigeria, cultural parlance, the concept of youth is devoid of chronological age limits. In terms of the implication of the age limit on youth unemployment phenomenon, it is instructive to emphasize that it affects the comparability of youth unemployment statistic across Nigeria.

Unemployment according to Jhingan (2011) is an unacceptable idleness of a person willing to work at 
prevailing labor payment system but still unable to find one. For the international Labor Organization (2010) the issue of unemployment borders on the fact that a country's population consist of the economically active and inactive component. The economically active population is those of working age group either working or seeking for paid workers. It is in this regards that ILO (2007 p.3) regards the employed as those individuals of 15 years and above that are

$>$ without a job of any type

> Available to start work in the next two weeks if offered employment but not seeking for one

$>$ Actively looking for work or have found one and is waiting to start it.

In recognition of the devastating aftermaths of this unrelenting unemployment generally, various levels of government in Nigeria have initiated multitudinous policies and programmes targeted at the reduction of the phenomenon of unemployment in the country. Some of these programmes and policies are the National Directorate of Employment (NDE) established in 1986, the implementation of the 6-3-3-4 educational policy, the better life programme for rural women, and the family support programme, the National Poverty Eradication Programme (NAPEP) and the National Economic Empowerment and Development Strategy (NEEDS) etc.

Regrettably, in spite of the implementation of some of these laudable programmes in Nigeria, it is disheartening to state that these catastrophic phenomenons have continued unabated. Rather than youth unemployment reduction there is surge in the levels and varieties of this social malaise.

It is against the foregoing problems that this paper intends to explore the issue of reducing youth unemployment through the use of social studies instrument and entrepreneurship education by providing vocational training centers that will be established at each local Government headquarter, which will promote gainful employment for sustainable self-employment.

\section{Entrepreneurship and Social Studies as a Tool for Youth Empowerment}

Within The context of their developmental role, social studies and entrepreneurship plays crucial role in youth empowerment by contributing to nation's wealth through increased production activities

$>$ creates job opportunities thereby enhancing the utilization of human resources

> breeds favorable grounds for innovation and invention leading to improved or new products and services

> creates a competitive environment therefore promoting effectiveness in production

> raises national and individual income whereby improving the general standard of living

$>$ provides services to the society through identification of customer needs and satisfying them in production

> those people working already in organizations can prepare themselves for eventual retirement through entrepreneur and social studies education

> Breeds innovativeness, creativity and flexibility in organization thereby necessitating new as well as improved products to have competitive advantages.

From the above analysis, one will be convinced that entrepreneurship and social studies education contribute a lot to the youth empowerment by viewing the objectives of social studies which is interwoven with the objective of entrepreneurship education shown below

> Social studies also create an awareness and understanding of our evolving social and physical environment as a whole in the natural man-made, cultural and spiritual resources together with rational uses and conservation of those resources for self-employment.

> Develop a capacity to learn and acquire certain skills including not only those of listening, speaking, reading and initiating but also those skills of hand and head together with those of observation, analysis and influence which are essential to forming of social-economic and political judgment which ensure the acquisition of that relevant body of knowledge and information which is an 
essential pre-requisite to personal development as well as to a positive personal contribution to the betterment of mankind in his business

> Develop in students positive attitude of togetherness, commandership and co-operation towards a healthy nation, the inculcation of appropriate values of honesty, hard work, fairness and justice at work and play, which enable an entrepreneur to interact well with his customer and clients

> Development of the ability to think reflectively and come to independent conclusion in business of any human endeavors.

Furthermore, human relation skills necessary for any entrepreneurship and social studies activity are learnt (Otaha 2010 p. 8) puts it thus, are pursuit of self-economic interest and maximization of gain which are the prime movers or motivators of people to go into business. Thus social studies motives enable entrepreneurs to interact properly with his customers, clients, creditors, competitors and the general public including tax authorities, policy makers and policy implementers.

Entrepreneurial education is not vocational education. However, the vocational education skills are incorporated in the innovation expectation of an entrepreneurial minded work force. Entrepreneurship education is education that prepares the students of social studies to have great positive mind set, positive self-efficacy, mindset that is creative, productive self-reliance and to have sharp focus to earn more for themselves and the society at large (Onyilofor, 2010).

\section{Recommendations}

Based on the findings of this paper, the following recommendations were made:

All institutions in Nigeria should establish faculty of entrepreneurship education so that by the time they graduate, they might have acquired entrepreneurship skills which empower them builds economic capacity for suitable livelihood.

There should be an entrepreneurship capacity building that is well equipped, in all the local government, state and federal capital city so that students that are jobless will go and learn entrepreneurship skills which will empower them to be self-employed so that social parasites like kidnappers, armed robbers, smugglers, fraudsters etc should be minimized or eradicated in Nigeria.

All students should offer entrepreneurship and social studies education in schools while guidance and counselor awareness will help them develop assertive spirit, initiative spirit, creative spirit, team spirit, helping spirit, collaborative spirit, project spirit, empathetic spirit, positive mind-set, etc. which will help them to be self-employed, have desirable behavior for self-actualization which are all aims and objectives of social studies in Nigeria.

Promotion of research should be encouraged, that is, special emphasis should be placed on scientific, technological and agricultural research, social studies education, entrepreneurship through paper counseling. Our Universities should link-up with other programmes and graduates training outside the country.

Government should also provide an enabling operating environment such as adequate security, stable supply of power, and empowering of specialized financial institution through the central bank of Nigeria to grant loans to social studies and entrepreneurship graduate.

In conclusion, if the entrepreneurship skills, social studies education are utilized, Nigeria which is characterized by high levels of volatility, uncertainty, complexity and ambiguity will be a thing of the past. Therefore, for any nation to move forward there is great need for its citizen as well as government to embrace dynamism as a tool for responding to fight unemployment, anti-social behavior by tackling the threats that stand on our way of achieving success through the study of entrepreneurship and social studies education, which help to reduce youth unemployment. 


\section{References}

Adaralagbe, A. (1982). The Nigeria Social Programme in NERDC: Social Studies Teaching: Issues and problems, begin Ethiope publisher corp.

Akinyele, A.M. (2000). Effects of Fiscal Deficit on Some Macro-Economic Aggregate in Nigeria. Final Report Submitted to the African Economic Research Consortium (AERC).

Federal Republic of Nigeria, (2008). National Policy on Education, $4^{\text {th }}$ Edition.

http://en.wikipediaorg/wiki/entrepreneurshipeducation 18:18, 30 Nov. 2007.

ILO, (2007). World Employment. www.ilo.oorg/publicenglishbureau/int/prits.

ILO, (2010). Meeting the Challenges of Rising Unemployment and Underdevelopment. Report submitted by the ILO's employment policy strategy formulation mission to Nigeria.

NDE (2007). National Directorate of Employment Enugu State Annual Report.

Jhingan, M.L. (2011). The Economic of Development and planning. Delhi 32 Vinda Publication (P) Ltd Nisha Enterprises.

Onuoha, J.C. (2012). Nigeria and Journal of Social Studies: A Journal of the Social Studies Association of Nigeria vol. 15(2)

Onyilofor, F.N.C (2010). Entrepreneurial Education for Visually Challenged: Implication for counseling. Nigeria Journal of Education Research, Officially Journal of Faculty of Education, University of Nigeria, vol. 1(10) 153-162.

Otaha, I.J. (2010). Public Policy Analysis and Entrepreneurial Development, issues, opportunities and Challenges. Abuja: Eriba publishing company,

Schumpeter, J. (1949). The Theory of Economic Development. Harvard University Press, Original German Edition.

Zaria, L.I. (2006). Fundamentals of Social Studies. Markudi: Vigo Printing Press.

Zuamo, J.T, and Aondoakaa, E.K. (2007). Basic Management and Entrepreneurship skills. Markudi: Traces Nig. Ltd 
